\title{
Jaringan Komunikasi Petani dalam Program Kartu Tani di Desa Bakalan Kecamatan Polokarto Kabupaten Sukoharjo
}

\author{
Diah Ayu Setyani*, Dwiningtyas Padmaningrum, Putri Permatasari
}

Program Studi Penyuluhan dan Komunikasi Pertanian, Fakultas Pertanian, Universitas Sebelas Maret

*Email: diahayu1196@gmail.com

\begin{abstract}
Abstrak
Informasi mengenai kartu tani sebagai inovasi baru perlu disebarluaskan kepada petani melalui jaringan komunikasi yang baik. Penelitian ini bertujuan untuk menganalisis peranan, menganalisis klik, dan menganalisis struktur jaringan komunikasi kartu tani yang terbentuk di Desa Bakalan, Kecamatan Polokarto, Kabupaten Sukoharjo. Penelitian ini menggunakan metode deskriptif kuantitatif. Lokasi penelitian di Desa Bakalan, Kecamatan Polokarto, Kabupaten Sukoharjo karena angka pengguna kartu tani di desa tersebut tergolong rendah. Metode pengambilan sampel menggunakan sampel kelompok kecil dengan cara mengambil seluruh anggota dari satu kelompok yang terdiri dari 59 orang petani. Analisis yang digunakan yaitu analisis sosiometri. Hasil penelitian menunjukkan bahwa peranan di Desa Bakalan terdiri dari opinion leader, bridge, dan neglectee. Klik yang terdapat di Desa Bakalan sebanyak 17 klik. Struktur jaringan yang meliputi kepadatan jaringan $($ density $)=0,026$, diameter jaringan $=5$, nilai derajat keterhubungan $($ connectedness $)=9,3 \%$. Pola jaringan komunikasi yang terbentuk di Desa Bakalan secara keseluruhan yaitu pola roda.
\end{abstract}

Kata Kunci: Inovasi; Jaringan Komunikasi; Kartu Tani; Sosiometri

\section{Pendahuluan}

Pembangunan pertanian di Indonesia sejatinya bertujuan untuk menyejahterakan petani salah satunya yaitu melalui subsidi input usahatani berupa pupuk, benih, maupun penerapan teknologi baru sehingga diharapkan dapat meningkatkan produksi pertanian. Menurut Soeminto (2000), salah satu alternatif untuk mendukung pembangunan pertanian adalah dengan melakukan pemupukan. Permasalahan yang terjadi khususnya terkait pupuk meliputi kelangkaan, harga yang fluktuatif, serta penggunaan pupuk oleh petani yang sering kali melebihi dosis anjuran. Kelangkaan pupuk bersubsidi terjadi karena kebutuhan akan pupuk yang tinggi sedangkan ketersediaan di tingkat pengecer/ distributor yang rendah, bahkan seringkali tidak tersedia sehingga mengakibatkan harga pupuk yang semakin meningkat dan kebutuhan pupuk petani kurang tercukupi. Hal tersebut terjadi karena ketidakmerataan distribusi pupuk bersubsidi baik di tingkat distributor wilayah maupun di tingkat petani.

Distribusi pupuk yang baik adalah yang memenuhi asas enam tepat yaitu tepat jumlah, jenis, waktu, tempat, mutu, dan harga. Sebagai upaya untuk meminimalisasi permasalahan dalam pengawasan, pengadaan, dan penyaluran pupuk bersubsidi serta implementasi, Pemerintah Provinsi Jawa Tengah bekerjasama dengan Bank BRI membuat aplikasi Sistem Informasi Manajemen Pertanian Indonesia (SIMPI) dan Kartu Tani untuk transaksi pembayaran pupuk bersubsidi. Kartu tani adalah kartu debit BRI co-branding yang digunakan secara khusus untuk membaca alokasi pupuk bersubsidi dan transaksi pembayaran pupuk bersubsidi di mesin Electronic Data Capture (EDC) BRI yang ditempatkan di pengecer serta dapat berfungsi untuk melakukan seluruh transaksi perbankan pada umumnya (Biro Infrastruktur dan SDA Provinsi Jawa Tengah, 2017).

Percepatan melalui sosialisasi penggunaan kartu tani terus dilakukan oleh pemerintah. Kabupaten Sukoharjo merupakan salah satu wilayah yang turut serta menerapkan program kartu tani di provinsi Jawa Tengah. Berdasarkan monitoring transaksi kartu tani di Provinsi Jawa Tengah periode Januari sampai dengan Juli 2019 menunjukkan bahwa Kabupaten Sukoharjo menempati posisi 13 dari 35 provinsi di Jawa Tengah. Namun, baru sekitar $41 \%$ kartu tani digunakan oleh petani untuk transaksi pupuk bersubsidi.

Berkaitan dengan pengenalan dan penyebaran kartu tani sebagai sebuah inovasi baru, posisi saluran komunikasi memiliki peran strategis sehingga akan diketahui bagaimana petani saling berkomunikasi dan bertukar informasi. Informasi ini dibutuhkan petani untuk meningkatkan pengetahuan, menentukan sikap, dan berujung pada tindakan atau perilaku apakah petani akan menerapkan inovasi tersebut atau tidak. Menurut Rogers (1983), keputusan petani dalam mengadopsi suatu inovasi dipengaruhi oleh beberapa faktor salah satunya adalah saluran komunikasi. Hubungan komunikasi interpersonal yang terjadi dalam saluran komunikasi ini akan membentuk sebuah jaringan komunikasi. Berdasarkan teori jaringan komunikasi, dalam pencarian informasi petani harus membangun struktur jaringan dengan tetangga dan sumber informasi lainnya (Littlejohn, 2009). Berdasarkan hal tersebut, peneliti tertarik untuk menganalisis peranan, klik, dan struktur yang terbentuk dalam jaringan komunikasi petani dalam program kartu tani di Desa Bakalan, Kecamatan Polokarto, Kabupaten Sukoharjo. 


\section{Kerangka Teori}

\section{1) Jaringan Komunikasi}

Menurut Rogers dan Kincaid (1981), jaringan komunikasi terdiri dari individu-individu yang saling berhubungan yang kemudian direlasikan oleh arus komunikasi dan informasi yang terpola. Hal tersebut dapat diartikan bahwa jaringan komunikasi ini melibatkan individu-individu yang saling terkoneksi akibat kepentingan hubungan komunikasi dan informasi yang terpola diantara mereka demi terpenuhinya maksud dan tujuan. Jaringan dalam ilmu komunikasi secara sederhana didefinisikan oleh Eriyanto (2014) sebagai seperangkat aktor yang mempunyai relasi dengan aktor lain dalam tipe relasi tertentu. Studi jaringan komunikasi menggambarkan relasi aktor (bisa orang, lembaga, perusahaan, negara dan sebagainya) satu dengan lainnya dalam struktur sosial tertentu. Ada dua kunci utama dari jaringan komunikasi, yaitu aktor dan relasi. Jaringan komunikasi melihat fenomena atau peristiwa dari sisi miko (aktor), bukan makro. Sedangkan relasi yaitu bagaimana aktor-aktor tersebut berinteraksi satu sama lain.

\section{2) Adopsi Inovasi}

Adopsi adalah suatu keputusan untuk menerapkan atau menggunakan inovasi. Adopsi lebih lanjut didefinisikan dalam proses penyuluhan pertanian sebagai proses penerimaan inovasi atau perubahan perilaku baik berupa pengetahuan (cognitive), sikap (affective), maupun keterampilan (psyho-motoric) pada diri seseorang setelah menerima inovasi yang disampaikan oleh penyuluh kepada masyarakat sasarannya. Penerimaan inovasi disini tidak sekedar "tahu", tetapi sampai benar-benar dapat melaksanakan atau menerapkannya dengan benar serta menghayatinya dalam kehidupan dan usahataninya (Mardikanto, 1996).

Inovasi menurut Rogers dan Shoemaker (1971) diartikan sebagai gagasan, tindakan, atau barang yang dianggap baru oleh seseorang. Kebaruan suatu inovasi dapat diukur secara subyektif menurut pandangan individu yang menangkapnya. Baru dalam ide-ide yang inovatif tidak berarti harus baru sama sekali. Suatu inovasi mungkin telah lama diketahui oleh seseorang beberapa waktu lalu tetapi ia belum mengembangkan sikap suka atau tidak suka terhadap inovasi tersebut.

\section{3) Keterkaitan Jaringan Komunikasi dan Adopsi Inovasi}

Keterkaitan antara jaringan komunikasi dengan adopsi inovasi terlihat dari adanya hubungan positif antara keterlibatan seseorang dalam jaringan komunikasi dengan tingkat adopsi inovasi mereka. Rogers dan Kincaid (1981) menemukan bahwa ibu-ibu yang terikat dalam suatu jaringan komunikasi terutama keanggotaannya dalam perkumpulan ibu-ibu, berdampak pada banyaknya ibu yang mengadopsi cara-cara berkeluarga berencana. Sedangkan ibu-ibu lain yang tidak terikat dalam jaringan komunikasi, hanya sedikit yang mengadopsi.

Penyebaran inovasi kepada masyarakat dalam kenyataannya tidak mudah. Rogers dan Shoemaker (1971) mengemukakan salah satu contoh kesulitan dalam penyebaran inovasi yaitu kegagalan dalam proses difusi kampanye air masak di Los Molinos (Peru). Kegagalan penyuluhan di Los Malinos disebabkan beberapa hal antara lain pesan yang disuluh bertentangan dengan norma budaya masyarakat setempat, penyuluh salah dalam merekrut kelompok acuan dan tidak melibatkan pemuka pendapat (opinion leader) untuk menyebarkan informasi yang bersifat persuasif.

\section{Metodologi}

\section{1) Lokasi dan Penentuan Sampel Penelitian}

Penelitian ini dilaksanakan pada Bulan Agustus September 2020 di Desa Bakalan, Kecamatan Polokarto, Kabupaten Sukoharjo. Penelitian ini menggunakan metode deskriptif kuantitatif dengan teknik wawancara menggunakan kuisioner. Penentuan populasi menggunakan pendekatan nominalis yang batasannya disesuaikan dengan tujuan penelitian yaitu hanya petani yang tergabung dalam Kelompok Tani Bakalan dan terdaftar sebagai penerima kartu tani yang dijadikan responden. Teknik penarikan sampel menggunakan sampel kelompok kecil dimana semua individu dalam kelompok dijadikan sampel. Menurut Eriyanto (2014), penarikan sampel kelompok kecil lebih baik karena lebih bisa menggambarkan jaringan keseluruhan. Sampel yang diteliti dalam penelitian ini adalah seluruh anggota Kelompok Tani Bakalan di Desa Bakalan yaitu sebanyak 59 orang petani yang telah terdaftar sebagai penerima kartu tani.

\section{2) Jenis dan Sumber Data}

Jenis data yang digunakan dalam penelitian ini adalah data primer dan data sekunder. Data primer didapatkan melalui wawancara dengan petani menggunakan kuisioner yang berisi pertanyaan sosiometri berupa pertanyaan "dari siapa seseorang memperoleh informasi tertentu”. Data sekunder didapatkan melalui lembaga dan juga instansi yaitu Balai Penyuluhan Pertanian Kecamatan Polokarto, Dinas Pertanian dan Perikanan Kabupaten Sukoharjo, serta Badan Pusat Statistik Kabupaten Sukoharjo berkaitan dengan dokumen-dokumen yang relevan.

\section{3) Teknik Analisis Data}

Data kemudian dianalisis menggunakan analisis sosiometri. Analisis sosiometri merupakan suatu metode untuk memperoleh data tentang hubungan sosial dalam suatu kelompok yang berukuran kecil sampai sedang (10-50 orang), berdasarkan preferensi pribadi antara anggotaanggota kelompok dari suatu sistem jaringan komunikasi. Seseorang dalam suatu sistem tersebut memilih dan dipilih dalam berinteraksi. Sistem jaringan komunikasi disini yang dimaksud adalah jaringan komunikasi pada program kartu tani. Data sosiometri diperoleh melalui pendekatan pertanyaan sosiometri berupa pertanyaan "dari siapa seseorang memperoleh informasi tertentu". Pertanyaan tersebut terdapat dalam kuisioner yang diajukan kepada seluruh responden. Jawaban dari respoden kemudian diolah dalam tabel hubungan komunikasi memilih dan dipililh dari setiap anggota. Melalui tabel tersebut data diolah menjadi matriks sosiometri dan diagram sosiogram. Sosiogram menggambarkan arus komunikasi secara utuh dalam bentuk 
grafis dan akan terlihat pola hubungan antar individu serta peran masing-masing dalam jaringan.

Prosedur pembuatan sosiogram secara singkat yaitu memindahkan data sosiometri dari kuisioner menjadi matriks hubungan. Kuisioner yang berisi pertanyaan sosiometri direkapitulasi kemudian dipindahkan dalam matriks hubungan melalui kolom matriks (memilih dan dipilih). Kemudian, menggambarkan diagram sosiogram menggunakan software Ucinet VI. Software Ucinet VI adalah perangkat lunak yang dikembangkan oleh Borgatti, Everret, dan Freeman untuk studi jaringan komunikasi atau jaringan sosial.

\section{Hasil}

\section{1) Keadaan Umum Lokasi Penelitian}

Secara keseluruhan, luas wilayah Kecamatan Polokarto yaitu seluas 6.218 Ha. Desa Bakalan merupakan salah satu desa yang terletak di Kecamatan Polokarto, Kabupaten Sukoharjo dengan luas 305 Ha. Terdiri dari lahan sawah seluas $214 \mathrm{Ha}$ dan lahan bukan sawah seluas $91 \mathrm{Ha}$. Desa Bakalan berjarak $5 \mathrm{~km}$ dari pusat pemerintahan Kecamatan Polokarto. Jumlah penduduk Desa Bakalan sebanyak 5.961 orang dengan jumlah usia produktif sebanyak 4.106 orang atau $68,88 \%$. Tingkat pendidikan penduduk Desa Bakalan sebagian besar adalah SD/sederajat dengan mata pencaharian mayoritas sebagai petani. Komoditas yang ditanam di Desa Bakalan adalah padi.

\section{2) Keadaan Kartu Tani di Desa Bakalan}

Desa Bakalan memiliki 4 kelompok tani yaitu kelompok Tani Makmur, Kenteng, Bakalan, dan Pondok yang semua anggotanya terdaftar sebagai penerima kartu tani. Namun, menurut data Sistem Informasi Manajemen Pertanian Indonesia (SIMPI) pada tahun 2019 terdapat satu kelompok tani yang pergerakan kartu taninya tidak tercatat di dalam aplikasi SIMPI yaitu kelompok tani Bakalan. Pergerakan tersebut akan terlihat apabila kartu tani digunakan oleh petani dalam setiap transaksi pembelian pupuk bersubsidi di kios pupuk yang sudah ditentukan.

Permasalahan tersebut disebabkan oleh beberapa faktor diantaranya informasi mengenai kartu tani kurang tersebar dengan baik, kurangnya keaktifan dari setiap anggota kelompok tani, kedisiplinan pemilik kios pupuk untuk mewajibkan pembelian pupuk bersubsidi menggunakan kartu tani, serta sosialisasi dan pendampingan yang kurang dari penyuluh atau pemerintah setempat. Kondisi 59 petani yang terdaftar dalam kelompok tani Bakalan kini sudah tidak aktif lagi mengadakan pertemuan kelompok, sehingga anggota kurang mendapatkan informasi mengenai kartu tani melalui pertemuan kelompok. Begitu juga dengan kegiatan penyuluhan yang jarang sekali diadakan oleh penyuluh.

\section{3) Peranan dalam Jaringan Komunikasi Kartu Tani di Desa Bakalan}

Peranan masing-masing individu dalam jaringan komunikasi perlu diketahui agar penyebaran informasi mengenai inovasi bisa dengan mudah dipahami dan diadopsi oleh petani. Analisis jaringan komunikasi digunakan untuk mengetahui gambaran interaksi anggota dan perannya dalam suatu sistem. Data diperoleh melalui pertanyaan sosiometri yaitu pertanyaan yang berkaitan dengan hubungan sosial dalam suatu kelompok. Hasil analisis digambarkan dalam bentuk sosiogram. Berikut ini merupakan hasil analisis jaringan komunikasi petani dalam program kartu tani di Kelompok Tani Bakalan, Desa Bakalan, Kecamatan Polokarto, Kabupaten Sukoharjo:

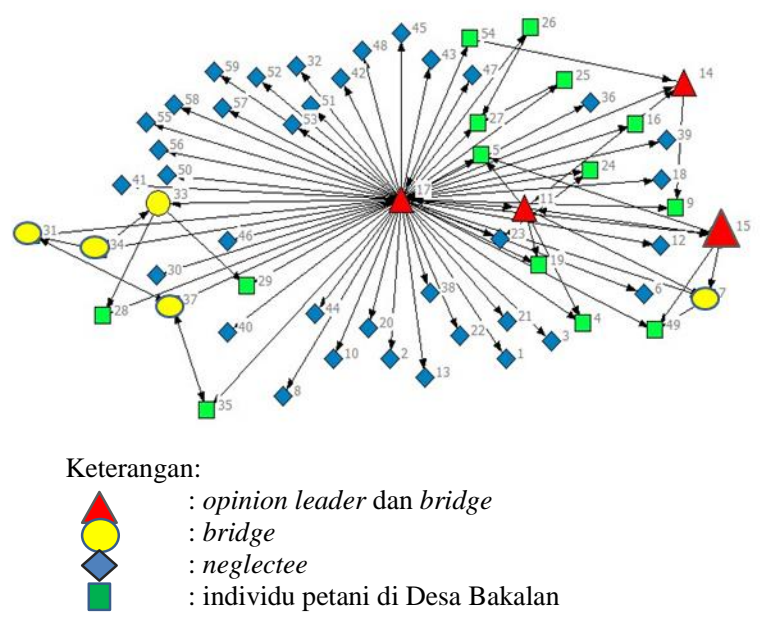

Gambar 1. Diagram Sosiogram Jaringan Komunikasi Kartu Tani di Desa Bakalan

Gambar 1 merupakan bentuk sosiogram hasil analisis jaringan komunikasi menggunakan aplikasi Ucinet VI. Hasil analisis terhadap 59 nodes (titik aktor dalam jaringan komunikasi) menunjukkan bahwa petani-petani di Kelompok Tani Bakalan memiliki beberapa peran yaitu opinion leader, bridge, dan neglectee. Peran opinion leader dilihat dari banyaknya link yang dimiliki, ditunjukkan dengan anak panah yang menuju petani dan keluar dari petani. Aktor yang berperan sebagai opinion leader adalah aktor dengan nomor 17, 14, 15, dan 11. Aktor 17 atas nama Siswanto, merupakan ketua kelompok tani. Hal tersebut sejalan dengan penelitian yang dilakukan oleh Cindoswari (2016) yang menyakan bahwa ketua kelompok tani berperan sebagai opinion leader. Aktor 17 menjadi aktor sentral dalam penyebaran informasi karena informasi mengenai kartu tani pertama kali disampaikan oleh ketua kepada anggotanya. Ketua kelompok juga bertugas mengumpulkan secara kolektif persyaratan untuk mendaftar sebagai penerima kartu tani seperti fotokopi e-KTP, tanda kepemilikan tanah, bukti setoran pajak tanah, dan bukti sewa. Ketua kelompok juga memiliki tanggung jawab berkaitan dengan pengairan lahan sawah yang ada di Desa Bakalan karena sebagian besar sawah menggunakan irigasi teknis. Bapak Siswanto sudah menjadi ketua kelompok tani sejak tahun 80an dan belum pernah digantikan. Aktor 11 dan 15 juga memiliki banyak link karena kedua aktor tersebut memiliki keterbukaan terhadap informasi. Aktor 11 dan 15 menyatakan kesediaannya untuk menggunakan kartu tani, namun kartu tersebut belum diterima sehingga aktor 11 dan 15 hanya berperan dalam penyebaran informasi saat awal kartu tani diluncurkan.

Peran bridge ditunjukkan oleh aktor 17, 11, 34, 31, $33,37,14,15$, dan 7 . Aktor 11, 34, 31, 33, 37, dan 15 
merupakan anggota kelompok tani yang memiliki kedekatan dengan opinion leader sehingga diharapkan dapat mempermudah dalam penyebaran inovasi. Namun pada kenyataannya, semua petani belum menggunakan kartu tani untuk membeli pupuk di kios pupuk yang sudah ditentukan bahkan banyak yang belum menerima kartu tani meskipun telah mengetahui informasinya. Beberapa petani yang sudah menerima kartu tani belum menganggap penting penggunaannya. Sebagian besar komunikasi yang terjalin dilakukan secara non formal seperti saat bertemu di warung atau saat berada di lahan karena sudah lama tidak diadakan pertemuan kelompok.

Peran neglectee ditunjukkan oleh aktor 1, 2, 3, 6, 8, $10,12,13,16,18,20,21,22,23,24,30,32,36,38,39,40$, $41,42,43,44,45,46,47,48,49,50,51,52,53,55,56,57$, 58 , dan 59. Semua peran neglectee tersebut merupakan anggota kelompok tani yang memilih orang lain sebagai sumber informasi namun tidak dipilih orang lain untuk dijadikan sumber informasi. Mereka hanya menerima informasi tanpa menyebarkannya. Hal tersebut terjadi karena mereka merasa ada petani lain yang lebih mengetahui dan sudah menyebarkan informasi tersebut.

Peran cosmopolite tidak ditemukan pada jaringan komunikasi di Desa Bakalan karena aktor-aktor opinion leader hanya bertukar informasi dengan petani lain namun masih berada di desa yang sama. Hal ini menunjukkan bahwa informasi mengenai kartu tani hanya berkutat di Desa Bakalan saja dan kurangnya relasi dengan pihak lain di luar desa. Peran liaison tidak ditemukan karena setiap petani yang berperan sebagai perantara merupakan anggota klik dalam jaringan komunikasi, sedangkan liaison merupakan seorang perantara namun bukan anggota klik. Peran isolate juga tidak terdapat dalam jaringan komunikasi di Desa Bakalan yang artinya seluruh responden setidaknya pernah menerima informasi mengenai kartu tani meskipun tidak disebarkan dan tidak pernah ditanya oleh petani lain.

Permasalahan yang paling banyak dibicarakan oleh petani yaitu mengenai cara menggunakan kartu tani, kemudian cara mendapatkan kartu tani tersebut, sementara untuk menfaat dari kartu tani sendiri mayoritas petani sudah mengetahuinya. Mayoritas petani sudah mengetahui informasi mengenai kartu tani namun belum menggunakannya untuk membeli pupuk bersubsidi bahkan ada yang belum menerimanya. Sebagian besar kartu tani ditumpuk di kios pupuk dan tidak digunakan untuk membeli pupuk bersubsidi. Awalnya dengan alasan agar tidak tertinggal saat akan membeli pupuk, tetapi lama kelamaan tidak digunakan dan mesin EDC (Electronic Data Capture) terkendala sinyal. Pemilik kios melayani pembelian pupuk bersubsidi hanya berdasarkan Rencana Definitif Kebutuhan Kelompok (RDKK) yang memuat data petani dan jumlah pupuk yang dibutuhkan. Hal tersebut membuat pergerakan pupuk bersubsidi tidak tercatat dalam Sistem Informasi Manajemen Pertanian Indonesia (SIMPI).

\section{4) Sentralitas Aktor dalam Jaringan}

Pertanyaan penting dalam studi analisis jaringan adalah siapa aktor yang paling menonjol dan menentukan dalam jaringan, serta seberapa sentral aktor tersebut dalam jaringan. Eriyanto (2014) menjelaskan beberapa ukuran sentralitas yang paling sering digunakan dalam studi jaringan yaitu sentralitas tingkatan, kedekatan, dan keperantaraan. Hasil analisis sentralitas berupa angka yang dapat digunakan untuk mengetahui siapa aktor yang menjadi rujukan petani ketika membutuhkan informasi dan juga untuk memperkuat gambar sosiogram di atas. Aktor diberi simbol berupa angka 1-59 sesuai dengan jumlah aktor yang diteliti yaitu 59 aktor/petani. Hasil analisis beberapa aktor sentral menggunakan software Ucinet VI tersaji pada tabel di bawah ini:

Tabel 1. Hasil Analisis Sentralitas Aktor

\begin{tabular}{ccccc}
\hline \multirow{2}{*}{ No. } & \multirow{2}{*}{ Aktor } & \multicolumn{3}{c}{ Sentralitas } \\
\cline { 3 - 5 } & & Tingkatan & Kedekatan & Keperantaraan \\
\hline 1. & 17 & 0,999 & 1,000 & 6,256 \\
2. & 11 & 0,171 & 0,540 & 1,709 \\
3. & 14 & 0,102 & 0,531 & 0,060 \\
4. & 15 & 0,102 & 0,376 & 0,010 \\
5. & 34 & 0,068 & 0,036 & 0,272 \\
6. & 31 & 0,068 & 0,037 & 0,242 \\
7. & 33 & 0,085 & 0,036 & 0,242 \\
8. & 37 & 0,085 & 0,037 & 0,181 \\
9. & 7 & 0,068 & 0,035 & 0,010 \\
\hline
\end{tabular}

Berdasarkan tabel 1 di atas dapat diketahui bahwa nilai akhir sentralitas tingkatan tertinggi yang nilainya lebih dari 0,1 dimiliki oleh aktor 17,11,14, dan 15. Aktor dengan nilai sentralitas tingkatan tertinggi disebut juga opinion leader dalam sebuah jaringan komunikasi. Aktor 17 merupakan ketua kelompok dan aktor 14 merupakan bendahara kelompok, sedangkan aktor 11 dan 15 merupakan anggota kelompok. Sentralitas tingkatan memperlihatkan popularitas aktor dalam jaringan. Seberapa banyak petani memilki relasi dengan petani lainnya di Desa Bakalan. Aktor 17 merupakan petani yang memiliki nilai sentralitas tertinggi. Hal ini menunjukkan aktor 17 menyebarkan informasi dengan baik dan menjadi rujukan petani lain untuk menanyakan informasi. Kemudian dilanjutkan dengan aktor 11, 14, dan 15.

Aspek selanjutnya yaitu kedekatan antar inidividu dalam jaringan komunikasi. Sentralitas kedekatan mengukur seberapa dekat individu bisa menghubungi individu lain untuk mendapatkan informasi. Kedekatan tersebut dilihat dari berapa link yang diperlukan untuk menghubungi atau dihubungi oleh individu lain. Tabel $1 \mathrm{di}$ atas menunjukkan aktor dengan nomor 17 memiliki nilai sentralitas kedekatan tertinggi. Disusul oleh aktor 11, 14, dan 15. Sentralitas kedekatan berbeda dengan sentralitas tingkatan. Sentralitas tingkatan merujuk pada banyaknya individu yang menjalin relasi atau kontak dengan individu lain, sedangkan sentralitas kedekatan menentukan seberapa dekat relasi individu yang satu dengan yang lain. Aktor dengan nilai sentralitas tingkatan yang tinggi belum tentu memiliki kedekatan yang tinggi pula terhadap aktor yang lain. Tetapi dalam jaringan komunikasi kartu tani di Desa Bakalan, aktor dengan nilai sentralitas tingkatan tertinggi juga memiliki nilai sentralitas kedekatan yang tinggi yaitu aktor dengan nomor 17. Kedekatan yang dimaksud yaitu aktor yang paling cepat dalam menjangkau semua aktor lain dalam jaringan, baik secara langsung maupun melewati perantara aktor lain. Angka sentralitas kedekatan adalah 0 1, dimana semakin mendekati 1 maka akan semakin baik. Nilai yang tinggi memperlihatkan dekatnya jarak rata-rata aktor dengan seluruh akor lainnya dalam jaringan. 
Sentralitas keperantaraan menunjukkan posisi aktor sebagai perantara dari relasi aktor satu dengan aktor lainnya dalam suatu jaringan. Tabel 1 di atas menunjukkan bahwa nilai keperantaraan tertinggi dimiliki oleh aktor 17 dengan nilai 6,256. Artinya, aktor 17 memiliki peran tinggi dalam menghubungkan petani satu dengan yang lain dalam menyebarkan informasi. Nilai sentralitas keperantaraan selanjutnya dimiliki oleh aktor $11,34,31,33,37,14,15$, dan 7. Aktor-aktor tersebut menempati peran sebagai bridge. Penyebaran peran sebegai perantara atau bridge yang sudah cukup meyeluruh seharusnya mampu memudahkan petani mengadopsi inovasi kartu tani. Tetapi walaupun sudah mendapatkan informasi megenai kartu tani, kenyataannya masih ada petani yang kurang tertarik menggunakan kartu tani karena alasan kurang praktis. Sebagian petani yang lain mengaku mau menggunakannya apabila kartu terdistribusi dengan baik dan juga didukung dengan ketersediaan pupuk di kios yang sudah ditentukan.

\section{5) Klik dalam Jaringan Komunikasi Kartu Tani di Desa Bakalan}

Klik merupakan kelompok kecil yang terbentuk dalam jaringan komunikasi. Kelompok kecil tersebut minimal terdiri dari tiga orang dan terbentuk karena adanya komunikasi dua arah antar petani (Eriyanto, 2014). Klik yang terbentuk dalam jaringan komunikasi kartu tani di Desa Bakalan disajikan pada Gambar 2 berikut:

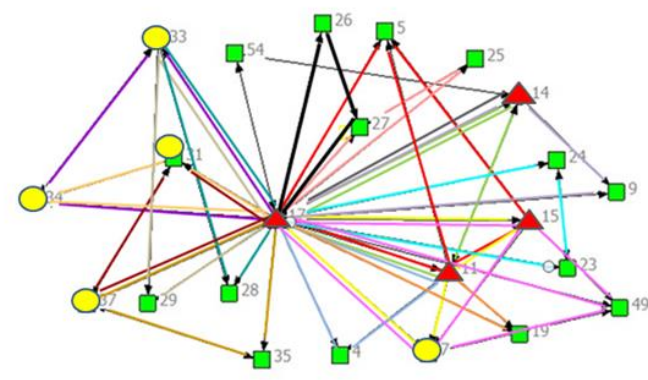

$\begin{array}{ll}\text { Klik 1: 5-11-15-17 } & \text { Klik 10: 17-28-33 } \\ \text { Klik 2: 7-11-15-17 } & \text { Klik 11: 17-29-33 } \\ \text { Klik 3: 11-14-17 } & \text { Klik 12: 17-31-34 } \\ \text { Klik 4: 4-11-17 } & \text { Klik 13: 17-31-37 } \\ \text { Klik 5: 11-17-19 } & \text { Klik 14: 17-33-34 } \\ \text { Klik 6: 9-14-17 } & \text { Klik 15: 17-35-37 } \\ \text { Klik 7: 17-23-24 } & \text { Klik 16: 7-15-17-49 } \\ \text { Klik 8: } 17-25-27 & \text { Klik 17: 14-17-54 }\end{array}$

Klik 9: 17-26-27

\section{Gambar 2. Klik Jaringan Kartu Tani di Desa Bakalan}

Hasil analisis klik di atas menunjukkan bahwa kelompok klik yang terbentuk di Desa Bakalan berjumlah 17 klik. Klik tersebut merupakan klik kecil karena tiap klik beranggotakan 3-4 orang. Anggota klik yang sedikit ini menunjukkan bahwa topik mengenai kartu tani kurang menarik bagi sebagian anggota untuk dibicarakan. Terlihat, anggota dari klik yang kurang bervariasi. Masih banyak anggota yang belum tergabung dalam klik atau tidak memiliki kelompok kecil. Klik kecil juga menunjukkan komunikasi yang kurang luas. Semakin banyak jumlah anggota dalam klik, maka semakin mudah informasi dikendalikan dan disebarkan. Agar memudahkan informasi diterima oleh setiap petani, dapat dilakukan pendekatan dengan minimal satu perwakilan dari setiap anggota klik. Klik dapat terbentuk apabila ada kedekatan antar anggota, bisa kedekatan tempat tinggal atau akrab secara komunikasi. Suatu informasi akan mudah diterima apabila diberikan oleh orang terdekat atau orang yang sudah dipercaya.

\section{5) Struktur Jaringan Kartu Tani di Desa Bakalan}

Menurut Eriyanto (2014), struktur jaringan menggambarkan gambaran umum dari jaringan komunikasi secara utuh (complete network). Struktur jaringan melibatkan semua anggota kelompok tani Bakalan dan relasi yang terbentuk dengan total 59 aktor. Pola jaringan yang terbentuk secara keseluruhan adalah pola roda. Pola roda menunjukkan bahwa sebagian besar petani di Desa Bakalan melakukan komunikasi yang terpusat pada opinion leader. Opinion leader masih menjadi rujukan dalam penyebaran informasi. Struktur jaringan komunikasi di Desa Bakalan disajikan dalam tabel 2 di bawah ini:

Tabel 2. Struktur Jaringan Komunikasi di Desa Bakalan

\begin{tabular}{lc}
\hline Struktur Jaringan Komunikasi & Nilai \\
\hline Kepadatan (density) & 0,026 \\
Diameter & 5,000 \\
Derajat Keterhubungan & 0,093 \\
\hline
\end{tabular}

Kepadatan memperlihatkan intensitas komunikasi antar anggota dalam jaringan. Jaringan dengan kepadatan tinggi adalah jaringan dimana anggotanya saling berkomunikasi satu sama lain. Sebaliknya, jaringan dengan kepadatan rendah menunjukkan minimnya interaksi dalam jaringan. Nilai kepadatan (density) jaringan yang sempurna adalah 1 (Eriyanto, 2014). Hasil analisis sosiometri pada tabel 5.4 menunjukkan bahwa nilai kepadatan (density) sebesar 0,026 yang berarti sangat rendah. Petani di Desa Bakalan memiliki relasi yang berlangsung kurang erat karena kurangnya intensitas komunikasi antar petani untuk membicarakan permasalahan kartu tani.

Nilai diameter jaringan komunikasi di Desa Bakalan adalah 5. Nilai tersebut berarti bahwa langkah terjauh seorang petani untuk menghubungi petani lain dalam jaringan adalah 5 langkah atau melalui 5 perantara. Secara teoritis, jaringan dengan ukuran kecil lebih sedikit pula langkah untuk bisa berinteraksi dengan orang lain. Sebaliknya, jaringan yang besar lebih banyak langkah atau jalur untuk bisa berinteraksi dengan orang lain.

Derajat keterhubungan menunjukkan luasnya hubungan komunikasi antara individu satu dengan yang lain dalam suatu jaringan. Nilai derajat keterhubungan jaringan komunikasi di Desa Bakalan adalah 0,093 atau sebesar 9,3\% yang berarati masih sangat rendah. Hal ini dikarenakan kurangnya antusiasme petani mengenai program kartu tani sehingga intensitas komunikasi mengenai kartu tani dikalangan petani juga rendah. Menurut Eriyanto (2014), semakin mendekati satu atau 100\%, maka proses penyebaran informasi akan semakin baik. 


\section{Kesimpulan}

Berdasarkan hasil analisis dan pembahasan jaringan komunikasi kartu tani di Desa Bakalan, diperoleh kesimpulan bahwa peranan petani yang terdapat dalam jaringan komunikasi Kartu Tani di Desa Bakalan yaitu opinion leader, bridge, dan neglectee. Sementara peran cosmopolite yang juga penting tidak terdapat dalam jaringan. Klik yang terbentuk di Desa Bakalan sebanyak 17 klik dengan anggota masing-masing klik yang kurang bervariasi sehingga masih banyak anggota yang tidak tergabung dalam sebuah klik atau kelompok kecil.

Struktur jaringan komunikasi yang terbentuk di Desa Bakalan yang terdiri dari nilai kepadatan (density) sebesar 0,026 yang berarti komunikasi atau relasi yang terjalin antar aktor atau petani kurang erat dan menyeluruh. Komunikasi yang terjadi masih didominasi oleh beberapa orang saja. Selanjutnya yaitu nilai diameter dalam jaringan komunikasi Kartu Tani di Desa Bakalan adalah 5. Nilai 5 tersebut berarti, jarak terjauh seorang petani untuk menghubungi petani lain adalah 5 langkah atau melalui 5 aktor lain. Kemudian nilai derajat keterhubungan (connectedness) di Desa Bakalan adalah 0,093 atau sebesar 9,3\%. Nilai Derajat keterhubungan 9,3\% menunjukkan kondisi penyebaran informasi Kartu Tani di Desa Bakalan masih tergolong rendah.

\section{Daftar Pustaka}

Biro Infrastruktur dan SDA Provinsi Jawa Tengah, 2017. Petunjuk Praktis Penggunaan Kartu Tani Melalui Sistem Informasi Pertanian Indonesia (SINPI).

Website: https://biroinfrasda.jatengprov.go.id/programkegiatan/kartutani, diakses tanggal 26 Juni 2019.

Cindoswari, A.R., 2016. Analisis struktur jaringan komunikasi dalam adaptasi ekonomi, sosial dan budaya pada paguyuban Babul Akhirat di Kota Batam. Jurnal Komunikasi 10 (2), 129-144.

Eriyanto, 2014. Analisis Jaringan Komunikasi. Kencana, Jakarta.

Littlejohn, S., \& Foss, K., 2009. Teori Komunikasi. Salemba Humanika, Jakarta.

Mardikanto, T., 1996. Penyuluhan Pembangunan Kehutanan. Departemen Kehutanan, Jakarta.

Rogers, E.M dan Shoemaker, F.F., 1971. Communication of Innovations. The Free Press, London.

Rogers, E.M., \& Kincaid, 1981. Communicaton Network: Toward a New Paradigm for Research. Collier macmillan Publisher, London.

Rogers, E.M., 1983. Diffusion of Innovations. Free Press, New York.

Soeminto, B., 2000. Pupuk-pupuk Alam. CV Karya Indah, Jakarta. 